Наталија Панас

natalia.panas@amu.edu.pl

Универзитет „Адам Мицкијевич“ у

Познању

Институт словенске филологије https://doi.org/10.18485/knjiz.2021.11.11.8

УДК: 821.162.1.09-94 Крајевска Т.

Оригинални научни чланак

\title{
Мемоари Теодоре Космовске Крајевске: еманципацијски дискурс о положају жена у Босни и Херцеговини ${ }^{1}$
}

У раду анализирам Мемоаре Пољакиње Теодоре (рођ. Космовске) Крајевске у контексту еманципацијског дискурса. Циљ је да у поменутом контексту укажем на стратегије деловања Крајевске на проширењу културне и телесне еманципације Босанки и да попуним лакуне у културној историји жена. Крајевска је радила као лекарка и учитељица у Босни и Херцеговини пуне 34 године те је оставила снажан утисак у босанској средини. Мемоари, као носилац памћења, значајни су из перспективе познавања историје жена, „њене историје“ (herstory), посебно историје муслиманки из БиХ које до тада нису имале гласа или су биле мање видљиве у својој култури. Такође су значајни као изузетан елемент стварања међународне или транснационалне мреже наратива женског ауторства уопште. Једна од истраживачких перспектива у контексту освајања места за „њену историју“у културном памћењу јесте искуство женског тела. У том контексту разматрам како разумевање женскости, кроз призму тела и његовог биолошког и полног/родног аспекта, утиче на процес заборављања/сећања и у вези с тим на присуство/одсуство нарације жена и о женама у културном памћењу. Позивам се, дакле, на појам рода и пола у тумачењу Марије Соларске (Maria Solarska) у раду Encyklopedia gender: pleć $w$ kulturze (Енциклопедија рода: пол у култури) и на опис односа женствености и власти код Агњешке Зембжуске (Agnieszka Zembrzuska) у Problem ślepoty rodzajowej u Michela Foucault (Проблем родног слепила код Мишела Фукоа). У тај теоријско-методолошки оквир стављам категорију културног памћења Алаиде Асман (Alaida Assmann) и користим је у корелацији са појмом телесности у раду Еве Хижи (Ewa Hyży) Kobieta. Ciało. Tożsamość. Teorie podmiotu w filozofii feministycznej końca XX wieku (Жена. Тело. Идентитет. Теорије субјекта у феминистичкој филозофији крајем 20. века). У раду следим еманципаторске кораке Крајевске која је едуковала и лечила Босанке, оштро их критикујући, али уз пуно разумевања, емпатије и наклоности. Аутобиографски записи Крајевске детаљно и на изузетно занимљив и посебан начин показују како је пољска лекарка утицала на процес еманципације Босанки.

Кључне речи: мемоари, „њена историја“, еманципацијски дискурс, културно памћење, Теодора Крајевска

Дефицит извора у културној историји жена је значајан и, кад гледамо из те перспективе, Мемоари ${ }^{2}$ Теодоре Космовске Крајевске (1854-1935, Teodora Kosmowska Krajewska) непроцењиви су за истраживаче еманципације жена. Они су од велике важности за реконструкцију недостајућих карика у процесу сећања. Њихова вредност за проучавање женског покрета је огромна, и то не само на Балкану него и у Пољској јер, као што је писао Јан Хулевич (Jan Hulewicz): 
[а]утобиографских докумената нису оставиле нити пионирке еманципације половине 19. века, [...] нити учеснице позитивистичких дискусија о „женском питању“ [...]. Нису писале о себи прве студенткиње иностраних и пољских универзитета [...] нити феминистичке боркиње на прелазу векова 19. и 20. (Hulewicz 1958: VII)

Мемоаре је приредила, написала увод и објавила тек 1989. године архивисткиња Богуслава Чајецка (Bogusława Czajecka). Породица ауторке је поделила с њом и додатни материјал захваљујући коме је могла да се упозна са животом Крајевске из перспективе догађаја који нису били представљени у Мемоарима. Ово је солидно припремљена текстуална грађа, а траг памћења који је оставила пољска лекарка чини се из многобројних разлога непроцењив. Међутим, Чајецка је представила њену делатност само у биографско-инвентарном контексту. Архивисткиња је урадила ипак први - треба с признањем нагласити - апсолутно неопходан корак, градећи тиме један од битних стубова и полазну тачку за даља, продубљена и детаљнија истраживања. С обзиром на то, одлучила сам да наставим та истраживања, те да текст Крајевске подвргнем интерпретацијској и контекстуалној анализи, посебно узимајући у обзир еманципацијске елементе делатности ауторке Мемоара. За мене је овде кључан појам „њене историје“ (herstory), што значи читање историје из перспективе учешћа жена у њој и материјалних трагова, стизања до извора женске историје те описа судбине женског покрета. Надовезујем се тиме на проблем преображавања културног памћења у којем има места за присутност жена. Битан елемент у том аспекту је женско тело - његово биолошко функционисање у култури, какву је улогу имало и како се то одражавало на положај жена у друштву. У вези с тим, у анализи Мемоара такође се ослањам на механизам биомоћи, појам који означава да се у корист власти омогућава регулација живота путем биолошке репродукције, а инструмент за то су јавне институције и њихово деловање у друштвеној свакодневници. Циљ анализе Мемоара јесте да у поменутом теоријско-методолошком оквиру покажем еманципацијске кораке Крајевске: од њеног образовања у иностранству, медицинског рада и едукацијског деловања међу Босанкама, па до веома значајног подухвата да Крајевска све то опише и остави траг за женско - пољско и босанско културно памћење. 


\section{Биографски нацрт}

Теодора Космовска Крајевска је рођена и одгојена у Варшави, на подручју које је тада политички припадало царској Русији. ${ }^{3}$ Доминантна околност пољског друштва друге половине 19. века било је непрекидно угњетавање од стране руске окупаторске владе. Детињство и младост Теодоре Космовске били су обележени процесима русификације. Ти процеси су снажно формирали њен карактер, чија је главна црта био отпор и протест. Упркос тадашњем руском образовном систему, породица је осигурала за Теодору и њених седам сестара темељно образовање у духу патриотизма и љубави према пољском језику и народној књижевности. Добро се сналазила како у хуманистичким тако и у природним наукама, а отац ју је ангажовао за посао око службене документације. После завршетка Друге женске гимназије у Варшави са званичном похвалом cum laude, Теодора је прихватила посао учитељице математике у јавној немачкој школи у Варшави. Венчала се 1876. године с Антонијем Крајевским (Antoni Krajewski), учесником јануарског устанка те учитељем класичне филологије, а њихова кућа је постала место састанака угледних пољских хуманиста и активиста. После преране смрти свог мужа 1880. године, Крајевска се латила приватне наставе пољског језика и књижевности. У то време опробала се и на пољу књижевног стваралаштва; пре свега писала је новеле, међу којима је објавила „Ану“ („Аnna“) („Kurier Codzienny”, 1882). Након тога је донела одлуку да жели наставити своје образовање, те је уписала медицинске студије у Женеви (1883), где се издржавала од скромних финансијских средстава. На пољском подручју едукација за жене је била сведена на минимум, а више студије биле су скоро недостижне. Под руском окупацијом могућност универзитетског образовања давало је путовање за Санкт-Петерсбург, но Крајевска није то узимала у обзир јер је Руско царство сматрала за агресора и није желела бити покорна ни по том питању. У границама аустријске окупације, међутим, жене нису имале никакво право на више образовање, ${ }^{4}$ нарочито на пољу медицине. ${ }^{5}$

Мада је студирање у иностранству било велика промена у њеном животу, у Мемоарима не посвећује много пажње том периоду. Године 1885. добила је диплому (baccalauréat) на Природно-математичком факултету (Faculté des Sciences Physiques et Naturelles), а после тога је наставила образовање, које је завршила докторском дисертацијом Recherches physiologiques sur la réaction de dégénérescence (Физиолошке студије дегенеративне реакције, 1892). За тај рад добила је награду, а ,још у време студија професор Макс Шифа (Max Schiff) позвао ју да буде асистенткиња на катедри за 
физиологију“ (Czajecka 1989: 10), што је било велико признање. Посао државне лекарке Аустријског царства стекла је путем конкурса Државне владе у Сарајеву. Откуд таква промена у каријери? Мада су се међу три окупиране пољске територије еманципацијске идеје (посебно питање вишег образовања) ${ }^{6}$ најслабије примиле у границама Аустроугарске, захваљујући релативном либерализму у другим деловима Хабзбуршке монархије, феминисткиње са осталих окупираних територија могле су се прикључивати еманципацијском покрету. Наглашавам ту чињеницу због тога што су управо у тим границама жене имале могућност да започну рад у лекарској струци и у области медицине. При томе, управо су у Босни и Херцеговини отворена прва места за државне лекарке. Очекујући месецима да добије држављанство Хабзбуршке монархије, Крајевска је после доласка у Беч учила српскохрватски језик код песника Тугомира Алауповића ${ }^{7}$ („Хрват-Бошњак, како је тада потписивао своје песме” [Krajewska 1989: 58]). Похађала је такође предавања тадашњих ауторитета у области медицине.

У марту 1893. године Крајевска је прихватила посао теренске лекарке у општини Доња Тузла, где је раније радила Чехиња, др Ана Бајерова (Anna Bajerova). Задаци који су јој додељени били су пре свега лечење муслиманки, као и пацијенткиња из целог тузланског округа, те оцена стања хигијене и здравља жена, што је дотад онемогућавао закон Курана, забрањујући страном мушкарцу да гледа женско тело. Давала је бесплатне консултације у амбуланти близу њеног стана, што су босанске муслиманке нерадо користиле, за разлику од католикиња (углавном Хрватица) или православних жена (већином Српкиња). Закључке сакупљене на основу медицинских истраживања која су трајала преко три године, Теодора Крајевска је представила на Другом међународном гинеколошком конгресу у Женеви (1896) на који је била позвана као стручњакиња. Предавање је било посвећено теми остеомалације, ${ }^{8}$ раније непознатој болести. Још исте године је на Међународном конгресу жена у Берлину представила своју делатност у Босни и Херцеговини.

Године 1899. Крајевска је била премештена из Тузле у Сарајево да држи течајеве о хигијени. У Мемоарима се сећа сатисфакције због новог посла и срдачног односа који је изградила с учесницама курсева. За разлику од Тузле, на новом радном месту болница је функционисала (ради од 1894. године до данас), ${ }^{9}$ а директор је био пољски лекар, др Леополд Глик (Leopold Glück). Одржавала је јако добре односе с њим и са лекарском средином. С Пољацима у Босни и Херцеговини деловала је у друштву „Пољски круг“, између осталог, држећи предавања из пољског језика, а догађаје из отаџбине нашироко је коментарисала у Мемоарима. 
Босни и Херцеговини је посветила 34 године свог професионалног рада и најбоље време свог живота: од 1893. до 1927. године. Њено дуго одсуство из родне средине и искљученост из пољског друштва које је у том периоду преживело много темељних геополитичких и социјалних промена (потреси Првог светског рата, поново стечена државност 1918. године), био је ипак један од узрока због којих се Крајевска после повратка у Пољску није снашла у новоформираној отаџбини. Скоро непозната пољској лекарској средини, имала је уску групу рођака и познаника, добијала је малу плату која је стизала нередовно, а уз то и њен вид је био све слабији. У Сарајево је отишла још само једанпут. Плод тог путовања је превод новеле „Ханумица“ Верке Шкурле Илијић $(1930)^{10}$ на пољски језик. Крајевска је умрла у Варшави 1935. у 81. години живота.

\section{Рад у Босни и Херцеговини: еманципаторска и другачија}

Током своје лекарске мисије Крајевска посматра Босну тог доба из етнографске и антрополошке перспективе те постаје двострука заступница: и пољске и босанске културе. С обзиром на мозаичност записа у Мемоарима, анализу њиховог функционисања у еманципацијском дискурсу нећу представити хронолошки, већ ћу почети управо од културолошког питања јер се с њим као првим Крајевска додирује после доласка у Босну:

У марту сам напокон напустила блистави Беч [...] те сам се брижна упутила на југ, ка Босни [...] Земља равна, празна, идемо право према југу. Ваљда је то најружнији део Аустро-угарске монархије. Тај комад присвојене словенске земље [...] кондуктер ми објашњава и показује поједине зграде: фабрика шпиритуса, рудник угља, солана, циглана и цели ред радничких кућа... Дакле, није толико лоше колико су ме плашили. Где има индустрије, рада, тамо и постоји тежња за цивилизацијом. (Krajewska 1989: 60)

Први утисци тог путовања доказују да је Крајевска одлазила у будућу отаџбину пуна страха, јаких предрасуда и негативних стереотипа. Спомиње речи општинског лекара, др Дулера (J. Duller): „да не треба да журим с почетком лекарске праксе, да пре свега упознам локално становништво, обичаје, празноверја, посебно међу муслиманима. Када стекнем поверење, пацијенти ће сами долазити код мене“ (Krajewska 1989: 61). У оно доба наметање стране културе Хабзбуршке империје било је изазов за владајући модел 
културе у Босни и Херцеговини - пре свега појава лекара и учитеља, а међу њима и Крајевске, и то у обема улогама. Као Друга и другачија, у очима локалног становништва представљала је пре свега опресивни систем аустроугарске владе над босанским становништвом. Теодора Крајевска изгледала им је као инструмент који Аустроугарска користи за испуњавање „цивилизацијске мисије“ према „заосталој“ Босни и Херцеговини. Ваља при томе имати на уму да је сама Крајевска имала лично искуство интензивне доминације Руског царства у родној средини - диктат културе и закона окупатора, дакле, искуство блиско искуству локалног становништва. Најпре је морала да оповргне ту предрасуду („Наша европска одећа узрокује неповерење“ [Krajewska 1989: 81]; „Швабица значи у Тузли међу Босанцима туђу особу с којом се не симпатизира“ [Krajewska 1989: 89]):

Од локалног народа који ствара основни утисак и чини већину, оштро се разликују туђи дошљаци које они зову Швабо, Швабица. Брзо сам то сазнала: чим сам дошла у муслиманску кућу слушкиња је рекла својој госпођи да је „дошла нека Швабица“. Наравно, одмах сам се побунила. Рекла сам да нисам Швабица него Пољакиња. Да бих објаснила националне разлике рекла сам да припадам народу чији је језик сличан босанском говору [...] - Кад ниси Швабица зашто носиш шешир? [...] За такав паланачки поглед на свет нисам нашла одговор. (Krajewska 1989: 62)

Чињеница да није припадала окупаторском народу који је говорио немачки била је толико битна да је могла спречити дистанцу или чак ксенофобију која је додатно отежавала њен ионако тежак рад. Крајевска је примила к срцу савет др Дулера. Њене антрополошко-социолошке белешке на тему друштвене структуре у тадашњој Босни (како обичајне тако и културне), представљају импресиван етнографски материјал. На почетку се бавила спољњим, дакле најприметнијим слојем културе, то јест, архитектуром града Тузле:

Куће са малим прозорима прекривеним с унутрашње стране дрвеним решеткама (мушепци), и куће које се налазе у двориштима или баштама ограђене високим зидом - то су муслиманске куће у којима су жене изоловане од вањског света. (Krajewska 1989: 61) 
Ово запажање указује на осетљивост Крајевске на женско питање. Путем описа архитектуре босанских кућа Пољакиња почиње проницати у загушљиве женске просторе. Заузима у њима почасно место прво као гошћа, а временом и као веома поштована особа. Користи свој положај за конструктивну критику те почиње ширити санитарна знања. У даљем тексту наводим опис ситуације током прославе Бајрама:

Када нови гост, тј. нова жена улази, одмах је једна од присутних жена пита за њено здравље, здравље мужа и породице. Она одговара, па пита домаћицу. Иста питања „како си“, одговор „добро дошао, хвала на питању“ те опет питање и опет одговор врте се бесконачно и почињу ме замарати. Када су сазнале да сам доктор и да сам излечила Исмета, почеле су пре свега питати да ли имам мужа и децу. Осим тога, интересовале су се за мој шешир, костим, пипале материјал моје хаљине. Чак ми се учинило да су хтеле да провере какав имам доњи веш. Пре свега деца. Када сам почела обраћати пажњу на њихов лош начин живота, недостатак ваздуха и сунца у затвореним собама, недостатак кретања, па на предуго дојење деце, слушале су пажљиво, а касније су почеле с пуно поверења говорити о својим тегобама. (Krajewska 1989: 70)

Дефинишући такво понашање као незрело и чак инфантилно, Крајевска потврђује чињеницу да је у тадашњој средини женски ум био посматран као ограничен, незрео, непромишљен, наиван. У исто време је обраћала пажњу на то да се такво стање ума међу муслиманкама намерно подржавало и учвршћавало у њиховој култури: максимално изоловане, нису имале прилику да се развијају, образују и да шире друштвене и културне контакте. Једноставна питања и одговори представљали су уобичајен однос с другима за које су те жене знале. Своја посматрања из посете муслиманској кући током Бајрама Пољакиња упоређује с прославом крсне славе: „код босанских Српкиња све се током пријема дешава слично као код муслиманки“, разликују се једино „оделом, интелигенцијом и већим самопоуздањем“ (Krajewska 1989: 75), што вреди нагласити с обзиром на већу културно-друштвену слободу православних жена. Поменуте муслиманке су под утицајем Крајевске у властити скучени круг примиле подстицај споља, те се у њима појавио трачак иницијативе у разговору и фасцинација способностима Пољакиње („Дивиле су се једногласно мојем познавању и брзини писања“ [Krajewska 1989: 70]). ${ }^{11}$ 
Друго, изванредно значајна ствар на пољу културе (са својим здравственохигијенским последицама) коју је запазила Крајевска јесте простор на који су жене биле осуђене - загушљиве собе у којима су изоловане од ваздуха и сунца. Проблем ограниченог, уопште непроветраваног простора који је био опасан за здравље, морао је бити јако битан будући да се у Мемоарима та тема појављује као лајтмотив у неколико наврата. ${ }^{12}$ Бошњакиње су се суочавале с ограничењима у сваком аспекту живота. Извор таквог стања ствари Крајевска је налазила у тадашњој интерпретацији Курана: ${ }^{13}$

Муслимани се много разликују од осталог становништва зато што је њихова религија, представљена у Курану, истовремено и вера, породична и друштвена етика те законодавство [...] Куран наређује добре обичаје и скроман начин одевања жена на улици и та наредба је током векова нарасла под утицајем фанатизма до те мере да је прерасла у изоловање жене од спољашњег света и осудила је на самоћу, занемаривање елементарних услова хигијене, недостатак покрета, сунца и светла. (Krajewska 1989: 71)

Ауторка указује на системско, комплексно установљавање граница развоја, хигијене, мобилности, па чак и одређену организацију свакодневице муслиманки, што је веома лоше утицало на њихово здравствено стање. Недостатак хигијене је у великој мери био подупиран сиромаштвом друштва, али није то био нужан разлог:

У целом Крешеву су муслиманске куће прљаве. У оближњој Фојници је сасвим супротно, у богатим кућама како и у најсиромашнијим уџерицама свугде је било чисто. Подови су били опрани, прозори отворени, жене, деца чисто обучена. (Krajewska 1989: 135)

Истражујући појаву остеомалације, ${ }^{14}$ Крајевска је запазила да етиологија лежи у конкретној култури јер и католици и муслимани живе у истим условима, али ту болест налази једино код муслиманских трудница (према извештају са Гинеколошког конгреса у Женеви):

Влажне куће су једини узрок те болести, предиспозиција за остеомалацију је у погрешном начину живота, недостатку ваздуха, сунца, у прераном развоју полног 
живота, у исцрпљености организма због честих порођаја и дуготрајног дојења. (Krajewska 1989: 136)

Медицинско знање заиста је захтевало и добро познавање културе и услова живота одређене средине. Због услова који произлазе из културе ислама у БиХ, откривање остеомалације могла је извршити само медицински образована жена. ${ }^{15}$ Како би се боље видео значај лечења те болести, наводим опис тешког случаја из пера Крајевске:

Друга жена бледа, исцрпљена, седи на поду, ноге заврнуте под себе у лук, врат јој се не види, глава пропала међу раменима, као да лежи у тањиру; глава спуштена, брада додирује испупчене грудне кости. Дигнути се не може, пузи, наслонивши се на руке, па подижући труп рече да има 26 година; јако млада се удала. Рађа децу сваке године, доји па поново затрудни. Током трудноће боле је кости, сваке године све више су криве. Последњи порођаји били су јако тешки. Деца су слаба, умиру. Жена чак и не зна колико је деце родила. (Krajewska 1989: 173)

Остеомалација је, дакле, носила за собом још једну „претњу“. Како је писала проф. др Нисвета Алиспахић: „Временом, болови би се пренијели на ноге, што је отежавало полне односе, а чега се несретна жена највише бојала.“16 Због немогућности да затрудни, жени је „претио“ развод јер није била у стању да изврши своју основну породичну улогу: ${ }^{17}$

једна од њих је изјавила да јој муж прети да ако му не роди сина, он ће њу да пусти, тј. да се разведе [...] развод код муслимана је неизмерно једноставан. Довољно је да муж каже својој жени - ниси више моја жена - и да то три пута понови, или да изговори: - ти си ми као мајка. (Krajewska 1989: 70)

„У анализи женских тела [Susan] Бордо користи Фукоово [Foucault] одређење послушног тела [docile body]. Ово тело следи [...] неухватљив идеал женскости, подлеже дисциплини те нормализацији““ (Нуżу 2012: 202). Његова непроменљива функција остаје репродукција, као главни разлог женске егзистенције у патријархалном систему који идентификује жену с природом: „порођај је као искуство маргинализован, повезан с понижењем и пожртвовањем, и на крају искључен из јавног дискурса па одбачен и од стране жена“ (Kołodziejczyk 2014: 401). На тај начин систем привезује њихова тела 
приватном простору кућа. Стид повезан с порођајем показан је међу муслиманкама тиме што су током рађања ћутале, померајући тиме границе приватне сфере до минимума:

Током порођаја муслиманске жене немају никакву негу ни помоћ ни од кога. Рађају саме. Велика је част муслиманске жене када се породи без икаквог гласа, тако да у суседној соби нико не сазна да жена рађа. Чудно је да због немогућности тражења помоћи од лекара-мушкарца, жене муслиманке нису имале довољно храбрости да између себе изаберу самообразовану бабицу. (Krajewska 1989: 99)

Овако понашање је још јаче маргинализовало женско тело јер је ограничавало чак и природну реакцију њихових тела, која је узрокована „хормонски управљаним процесом порођаја (нпр. адреналином, окситоцином, ендорфинима) и емоцијама које они изазивају (узбуђење, страх, бол, екстазу)“ (Kołodziejczyk 2014: 401). Затворене у скученом кућном кругу муслиманке су понављале погрешне праксе, подржаване различитим веровањима:

стиже млада, прилично лепа смеђокоса жена и пита шта да ради јер њеном детету испада црево из чмара. Тражим да донесе дете и покаже. Тада са осмехом и збуњеношћу каже да нема потребе да показује дете [...] - одлази. За који тренутак враћа се и доноси дете замотано у јорган. Запазила сам да ово тромесечно дете има на лицу и на рукама смеђе мрље, покривене тамном длаком. Тражила сам да жена одмота јорган и пелене, напокон мајка је одлучила и показала дете. Цео доњи део трупа, натколенице скоро до колена покривене тамносмеђим мрљама са тамном длаком; облик натколеница и нога личио је на козу. Изгледа као фауна женског пола. Израз лица мајке био је чудан, као да је забринута, па опет као да се тајанствено смеје. - Загледала се у јарца - рекла је једна од старијих жена. Друге жене су гледале апатично на чудовиште, нису показивале запањеност. (Krajewska 1989: 137)

Наведени симптоми указују на релативно честе генетске деформације. Живећи у малим срединама, чланови и чланице те заједнице обично нису имали широке могућности да изаберу мужа, односно жену с којима уопште нису били у сродству. Овако су настајале промене у изгледу које су могле бити извор празноверја, на пример о клетви у породици. Одсуство чуђења окупљених жена може да сугерише да су се мутације појављивале доста 
често, подржаване веровањима у надрилекарске праксе те непромишљеним „курацијама“.

Путовала сам и свугде налазила заосталост, још веће празноверје и много горе услове него у Тузли. Уопште, муслиманске жене биле су осуђене на седење код куће, труднице се уопште нису померале с места чекајући порођај. У последњем месецу трудноће наређивано им је да пију рибље уље, чак лети, на температури од $37 \mathrm{R}\left[46,25^{\circ} \mathrm{C}\right]$. (Krajewska 1989: 99)

Тела трудница била су довођена до граница животне способности. У случају да су се појављивали проблеми, у првом реду дозиване су надрилекарке које нису имале знања о порођајима али су вршиле ритуале: на пример, жена која се порађала морала је да попије воду из десне чизме свог мужа, па да три пута пређе преко сита. ${ }^{18}$

Ако ни чизма ни сито нису помогли, породиља је морала да стрпљиво чека, чучећи у турском седу, придржавана уз помоћ надрилекарке. Када је друштво видело да је жена близу несвестице, тада је било дозвољено звати лекара, да у случају смрти породиље не буде сахрањена са дететом у утроби. (Krajewska 1989: 66)

Овакво тело је било једино инструмент за испоручивање потомака, а иза његове биологије нестајао је идентитет жене. Крајевска је горко приметила: „Очито, смртност је била велика, за статистику није нико бринуо, а муж који је постао удовац брзо се женио поново“ (Krajewska 1989: 99). Овде треба обратити пажњу на улогу супруга. „Мужеви су различити, напредни и заостали. У малим градовима дешавали су се случајеви потпуног злостављања жена од стране мужева. Напредни муслимани имају поштовање према женама““ (Krajewska 1989: 71-72). Узрок фаталног положаја жене видела у назадном понашању мужева: „када муслиманка оболи, није било дозвољено звати лекара јер мушкарац није смео да је види. Понекад, као изузетак, муж је дозвољавао жени да истури руку кроз врата да лекар провери пулс“ (Krajewska 1989: 71), а „током епидемије колере дешавало се да муслиман није пријављивао оболеле жене, што је било обавезно налогом градске управе“ (Krajewska 1989: 82). Дакле, жена је била заправо осуђена на мужевљеву вољу, ниво образовања, развој и личне особине. Ипак, вишеструка приврженост жена религијским правилима понекад је савладавала и одлучну способност мужа: 
Ни моје ни мужевљево наговарање ништа није помогло. На све наше молбе и аргументе одговарала је: - Нећу да се љечим, Бог дао. Шта да се ради? Туробно је било сељаку. Докторицу је довео узалуд, жена болесна и глупа па неће да се лечи [...] Остао је неугодан осећај неуспеха. Шта да се ради? Заосталост, празноверје, фанатизам. (Krajewska 1989: 80)

Жене су често биле неповерљиве у односу на нове методе лечења, чак и непријатељски расположене према раду Крајевске:

Када долазим код њих скоро да не одговарају на моја питања, гледају ме мрко, са неверицом. Ако дођем други пут и видим побољшање, онда одговарају на моје питање да је исто као пре или све горе [...] чак не зна изразити бес; само ме гледа љутим очима и миче уснама, као да нешто жваће или да хоће да испљуне свој пригушени бес. (Krajewska 1989: 82)

Проблем недостатка адекватне комуникације или реаговања на нова искуства могао је произлазити из изолације која је довела до интелектуалне пасивности. Део тих жена одржавао је

[...] само међусобне везе. Немају појма ко је лекар, лекарски преглед или савет. У ствари, долазе једино по лек и примају га јако радо јер су навикле узимати различите лекове од надрилекара и надрилекарки. Када им објашњавам како да користе такво средство, труде се да ме схвате. (Krajewska 1989: 178-179)

На тај начин муслиманке (само о њима у том контексту пише Крајевска) полако су признавале нову лекарку и њене методе. Жене које су лакше веровале „свему шта доноси напредак“ (Krajewska 1989: 82) сачињавале су мању групу и представљале углавном елиту муслиманског друштва.

Женско тело је, према извештају Крајевске, сасвим подређено културном контексту чије су норме одређене Кураном. ${ }^{19}$ Остали аспекти идентитета жена били су гурнути у најдаљи план њиховог свесног живота и развоја, остављајући место за идеје повезане с патријархалном интерпретацијом стварности. Крајевска је својим медицинским и образовним радом уводила жене у знање о телу. То је чинила преко лекарских упутстава, али и као наставница хигијене у неколико школа, што је донело 
проширивање знања муслиманки и њихов напредак. Тиме је избегла замку биомоћи обраћање соматском и биолошком аспекту тела није потиснуло питања еманципације интегралног идентитета. Иако је окупаторска влада морала да ради у име „просветне мисије“ Хабзбуршке монархије - како доказује Џевад Сулејманпашић у свом манифесту (цензурисаном 1913. године) у корист ослобођења муслиманки од покривања главе и лица - она, у ствари, није тежила да подигне свест босанског друштва, него да то друштво контролише. ${ }^{20}$ Сулејманпашић је био један од представника малобројне босанске интелигенције која је после образовања у европским школама донела у Босну еманципаторске идеје. Нажалост, присталице тих идеја сусретале су се не само с цензуром окупаторске владе - иако су се, теоријски, уклапале у став аустроугарске мисије - већ и с отпором локалних конзервативаца. Ослободилачке мисли садржане у паролама еманципације жена имале су потенцијал да обухвате друге групе, посебно националне покрете у Босни и Херцеговини. С једне стране, била је то опасност за стабилизацију вишеетничке Аустроугарске империје, с друге - за конзервативне струје међу муслиманима значило је револуцију и поремећај реда патријархалне хијерархије, ослоњене на власт верских вођа. ${ }^{21}$

Напоре Крајевске да извршава професионалне задатке, али и да се сналази у средини у којој живе њене пацијенткиње и пацијенти, отежавали су односи с управницима и другим лекарима. Пољакиња је била једна од само четири лекарке запослене од стране аустроугарске владе у Босни. Од њих је зависило не само здравље муслиманки (масовна вакцинација и лекарски савети, а у случају Крајевске такође и настава хигијене), него и здравље читавог босанског друштва. Контакт с болеснима није био ограничен на посете у амбуланти, него је био повезан с приватним посетама, радом у болници (после премештања у Сарајево) те лекарским путовањима у друге градове и села.

Оптерећени смо радом преко сваке мере, не мислим женске мере, него уопште преко људске мере. Општинска влада није узимала у обзир чињенице да је због планинског терена рад лекара у Сарајеву неизмерно отежан и да су путовања у сарајевској општини јако напорна. (Krajewska 1989: 124)

Неспособност чиновника у организацији и планирању посла, стална пожртвованост и стање непрекидне спремности ${ }^{22}$ чак су и тело саме Крајевске излагале напору до граница патње, штавише и до самоубилачких мисли: 
Морална потиштеност још превазилази физичку немоћ. Преплићу се појмови, због неке жалости која још није дошла до пуне свести навиру ми сузе. Плачем. Појављује се облик утехе - смрт. Да, нашла сам излаз из моје невоље - умрети... (Krajewska 1989: 127)

Много је ситуација показало да је Крајевска изградила у себи „другу нарав“, реагујући одлучно и мислећи јасно у кризним моментима. ${ }^{23}$ Доказујући свој професионализам, нарушава стереотипне тврдње о слабости „женске психе“ или неспособности жене да испуни лекарске дужности које су захтевне и научно и физички. Поред тога, Крајевска бележи дискриминационе поступке чиновника према женама - Пољакиња је наилазила на омаловажавање ефикасности свог рада због пола.

Овај пут осећала сам се јако уморно, али не физички него духовно. Мушкарци који праве паралелу између рада лекарки и рада лекара тврде да је рад жена мање продуктиван зато што су жене физички слабије од мушкараца и не јашу (!!). Тако су тврдили шеф Санитарног департмана др Колбер и његови чиновници. Чудан критеријум за оцену лекарског рада. (Krajewska 1989: 178)

Ментални и физички напор на послу ${ }^{24}$ био је несразмеран у односу на скромну плату, што представља још једну дискриминацију, родну и економску, финансијску. ${ }^{25}$

\section{О видљивости женског тела у јавном простору}

На овом месту желим да скренем пажњу на шири проблем посматрања тела и утицаја на место жена у друштвеном простору, јер су Мемоари Теодоре Крајевске непроцењив извор рефлексије и инспирације на ту тему. Они дозвољавају да се перспектива прошири и да се покаже колико интригантан може да буде начин женског историјског памћења управо кроз призму тела. За теорију биомоћи темељна је парадигма тела које је предмет институционалне контроле власти. Културно памћење (c.f. Assmann 2013), обликујући осећање дужности према колективном и идеји заједнице (на пример етничкој, народној или верској), може да постане оружје те биомоћи јер користи исте начине комуникације, а то су институције. „Позивањем на родно памћење захтева се такође размишљање о просторним односима. [...] Не уређује га више политички или 
територијалан поредак него тзв. искуство жена, повезано са женским телом“ (Solarska 2014: 367). Појам женствености ${ }^{26}$ као показатеља рода приписаног полу понавља се и репродукује у узастопним друштвеним перцепцијама које су конституисане као једини правилни погледи на тела (свих полова) и односе међу њима. Као што каже Зембжуска, „битна црта дисциплинарне власти усмерене на произвођење ‘женскости’ у телима жена, јесте [...] њена расејаност и анонимност“ (Zembrzuska 2005: 4). Она је детерминисала неприсутност слике женског тела помоћу укључујућег искључења, то јест, подређивања тела жена друштвеним правилима, што доводи до њиховог искључења из памћења о том друштву. Управо овде треба тражити полазну тачку за еманципацију жена преко промене нормативности културног памћења у ком женска сећања и приче о женама треба да буду присутне. Наглашавам у којој мери се то одразило у делатности Крајевске и у њеном искуству. Прво, ауторка је детаљно описала емпиријске доживљаје тела од најранијих успомена свог детињства, наглашавајући умор, болести, процесе лечења тела. Због тога што је дала израз тим искуствима - путујући широм Хабзбуршке империје и радећи у компликованим и често тешким друштвено-културним условима и неповољним теренским условима - створила је ненормативну слику ограниченог тела која је генерисана као последица културног памћења (стереотипизације женствености обликоване традицијом и предрасудама). Даље, она скреће пажњу на телесност других жена - посматра их кроз призму културних и обичајних разлика, али, пре свега, као најзанимљивија показује се медицинска перспектива повезана с еманципацијском. Крајевска је тела жена у Босни и Херцеговини „довела до присутности“ и учинила видљивим помоћу Мемоара - обратила је на њих пажњу, истраживала и објављивала научна посматрања и закључке у европској медицинској периодици. Изразито се види да је радила на побољшању здравствене свести босанских жена кроз њихово образовање, што се показало као кључ успеха. Другим речима, образовање је започело процес еманципације, нарочито за муслиманке, захваљујући томе што је Крајевска скренула пажњу на њихова тела те започела борбу против спољашњих системских ограничења. Друштвена слика женских тела која је условила њихову физичку и биолошку ситуацију била је истовремено једина слика тела коју су могле да запазе, упознају и прате. Функционишући у ограниченом хоризонту сазнања подвргавале су се рутини - „у будућности виде одраз прошлости“ (Beauvoir 2017: 684). Женско искуство Крајевске приближило ју је женама које су биле маргинализоване. Испоставило се да је један од главних начина њихове споре еманципације и спасења од заборава експресија искустава тела и истраживање тих искустава, на чему је радила пољска лекарка. 
На примеру Крајевске види се колико су аутобиографски записи кључни за реконструкцију еманципаторских процеса и културне историје жена у Босни и Херцеговини. Они су непроцењиви за креирање новог погледа на прошлост. У процесу новог читања сазнајемо како је чин бележења и стварања личних сведочанстава и докумената епохе био тежак. Текстови као што су Мемоари Теодоре Крајевске упућују на то да је труд неопходан и у случају ауторке која ствара културолошку и медицинску грађу чувајући памћење о женама у историји. Са̂м процес бележења опсервација о другим женама постаје такође поступак аутонарације о сопственим проблемима и препрекама жене која је учествовала у процесима женске еманципације.

„Почела сам писати и размишљам о датуму, размишљам који је то дан и који месец. Треба да урадим неки напор да напишем тих неколико речи“ - ово је исповест из 1902. године, а допуњена је фрагментом писма сестричини из 1932: „Жао ми је што нисам отпочела рад на мемоарима 10 година раније. Била бих то урадила да сам тад имала довољно средстава за живот [...] Сада ми недостаје жара“ (Czajecka 1989: 21).

Јасно се показује, дакле, и утицај економске дискриминације жена с обзиром на висину њихове плате. Економско искључење је одузимало могућност да се жене укључе у јавну сферу, што је последично имало утицаја на процес изградње памћења о тим женама. Болести Крајевске, умор и ниски животни материјални стандарди, упркос изврсним квалификацијама, посредно су допринели тешкоћама везаним за писање дневника, као и ограничењима вредног садржаја у њима: „Дневници су после њене смрти били уништени иако је питање њиховог очувања и објављивања било предмет посебне бриге ауторке“ (Czajecka 1989: 20).

\section{Закључак}

Анализа Мемоара Теодоре Крајевске у контексту еманципацијског дискурса показала је колико је вишеструк и компликован процес који је женама представљеним у наративу ауторке донео почетак слободе. Њен modus operandi биле су тежње ка равноправности реализоване помоћу рада на едукацији и ширењу медицинског знања. Ова стратегија је нашла подршку у индивидуалном и групном женском искуству. Као прво, битан је аутобиографизам као стратегија грађења „њене историје“ и потреба да се запише сопствена прича из перспективе научног искуства. Исто тако, важно је и записивање фрагмената памћења и историје жена из других култура и њихово очување на страницама сопствених успомена. Треће, биле су јако важне политике релације, дакле 
однос жена с институцијама власти, њихови покушаји да се сналазе у захтевном друштвеном и професионалном раду. Ово искуство било је детерминисано на различите начине, а пре свега представљањем жене као објекта, опредмећујућим сликама жена, концентрисаним на њихову телесност. Једно од посебних средстава еманципације - које се испоставило као важан фактор у рушењу патријархалних ограничења постављених женама - било је обраћање пажње на питања тела путем лечења и едукације жена. Ауторка је одиграла значајну улогу старатељке и био је то главни пут за продор у јавност и професионалну делатност: радила је ипак у оквирима здравствене установе - једне од оних које је влада интензивно искориштавала за контролу над биолошким особинама појединаца. Захваљујући својој вишеструкој активности лекара, наставнице хигијене и истраживачког рада, постигла је научни успех у виду дијагнозе и описа нове болести, већ поменуте остеомалације. Перспектива телесности као слике учвршћене патријархалном доминантом и преношене помоћу канона културног памћења испоставила се као веома користан истраживачки поглед у еманципацијском аспекту памћења. Сами Мемоари су запис механизама који су се указали у еманципаторским процесима у Пољској те у Босни и Херцеговини, па и шире у Аустроугарској монархији, заједно са стратегијом искоришћавања оружја биомоћи.

\footnotetext{
${ }^{1}$ Овај текст је настао у оквиру пројекта Preludium Bis 2 broj UMO-2020/39/O/HS2/02719: Cultural Memory and the Serbian Emancipatory Discourse in Autobiographical Texts by Female Authors (19th20th century) који је финансиран од стране Националног научног центра (National Science Centre, Poland) у Пољској.

2 Teodora Krajewska, Pamiętnik, ur. Bogusława Czajecka (Kraków: Krajowa Agencja Wydawnicza, 1989).

${ }^{3}$ У периоду 1772-1795. царска Русија, Хабзбуршка империја и Пруска постепено су делиле Пољску, која од 1795. па чак до 1918. није имала државност и није постојала на политичкој мапи Европе. Ипак, на свакој од окупираних територија Пољаци су се трудили да негују сопствену националну свест и идентитет упркос све јачим процесима германизације и русификације. Битни су у том периоду народноослободилачки устанци против царске Русије: тзв. Новембарски устанак 1830/1831, те Јануарски устанак који је почео 1863 . године, а завршио се тек у новембру 1864. Јануарски устанак има у пољској култури изразиту симболику борбе са руском доминацијом. После слома Јануарског устанка извршена је тотална русификација остатака пољске администрације и школства, наступиле су бруталне репресије. Истовремено, с крајем Првог светског рата, после 123 године непостојања на карти Европе, 11. новембра 1918. године, настала је Друга Република Пољска. Треба нагласити, да су заједно с тим догађајем, Пољакиње у 1918. години добиле, у напорној борби, право гласа.

${ }^{4}$ Више о томе: Urszula Górska, Drogi wolności: ruch emancypacyjny kobiet w monarchii habsburskiej na podstawie publicystyki i twórczości literackiej w latach 1867-1918 (Warszawa: Instytut Badań Literackich PAN, 2016).

${ }^{5}$ Један од гласова који је репрезентовао однос тадашњих образованих пољских мушкараца према школовању Пољакиња на универзитетима био је Хенрик Нусбаум (Henryk Nusbaum), неуролог, физиолог, филозоф медицине и публициста: „Завршавајући своје излагање доктор је показао професију прикладну за жене. Постулирао је да је уместо путовања у иностранство и студирања боље да се жене образују у педагошкој струци. 'Виши педагошки курсеви за жене, то је, по нашем
} 
мишљењу, неопходна потреба - стопут већа него потреба за вишим лекарским курсевима. Добрих лекара је скоро превише - добрих васпитачица премало!' На тај начин жене су биле 'послане' на службу народу којем више треба учитељица и васпитачица него конкуренткиња на мушком лекарском тржишту“ (Duda 2016: 27).

6 Значајне личности и припаднице пољског женског покрета које су студирале у иностранству, jecy: Паулина Кучалска-Рајншмит (Paulina Kuczalska-Reinschmit), оснивачица највеће пољске организације сифражеткиња, Савеза равноправности пољских жена, која је основала и уређивала радикални феминистички часопис Ster, др Јустина Буђинска-Тилицка (Justyna BudzińskaTylicka), суоснивачица Petite Entente des Femmes - Мале женске антанте која је сарађивала с Колом српских сестара, др Софија Дашињска-Голињска (Zofia Daszyńska-Golińska), сенаторка, економисткиња, ауторка, између осталог, феминистичког манифеста „Наш програм“.

${ }^{7}$ Будући професор и ментор Иве Андрића у гимназији у Сарајеву.

8 „Остеомалација је општи метаболички поремећај костију који карактерише дефектна минерализација. Као резултат тога, накупља се неминерализовани остеоид, па се губи снага костију. Главни узрок остеомалације је недостатак витамина Д.“ https://czytelniamedyczna.pl/1551,osteomalacja.html (преузето 15. 7. 2021).

${ }^{9}$ Види: https://www.kcus.ba/historija_kcus.html (преузето 15. 7. 2021).

${ }^{10}$ Види више: Verka Škurla-Ilijić, „Hanumica“, Bluszcz. Społeczno literacki ilustrowany tygodnik $\begin{array}{llllllllll}\text { kobiecy } & 1930.03 .15 & \mathrm{R} & 63 & \mathrm{nr} & 11, & 20 . & - & \text { превод } & \text { у прилогу }\end{array}$ http://www.wbc.poznan.pl/dlibra/publication?id=90511\&tab=3 (преузето 27. 12. 2017).

${ }^{11}$ Касније такође: „Старија Ферида изразила је жељу да научи писати и читати. Дотад нико од учитеља хришћана није имао такав утицај на женску муслиманску младеж“ (Krajewska 1989: 82). 12 „Ферида и њена мајка жалиле су се на конзерватизам муслиманског становништва и изоловање муслиманских жена. Богатије имају претежно башту поред куће или предградску вилу; дакле, не пате толико због затварања. Но, жене занатлија, нижих чиновника, учитеља - станујући у кући која се састоји од две собе, кухиње и малог трема с прозорима затвореним и ограђеним решетком - не могу издржати ту робију. Удатој жени дозвољено је да посети своју мајку, а лети да иде код пријатеља на село на излет“ (Krajewska 1989: 83); „Седе у једној ниској и прљавој соби. Атмосфера је неподношљива. Састоји се од различитих мириса: мирис лошег дувана, мирис прљавштине, зноја, стално сушених пелена, менструације, ветрова, подригивања на лук после недавно поједеног ручка“" (Krajewska 1989: 136).

${ }^{13}$ Потврда строгости у принципима заснованих на тадашњој интерпретацији Курана може се наћи у каснијем раду: „Нема на свијету конфесије која би својим сљедбеницама давала не само точне метафизичке догме, него која би давала и тако точне прописе за цијели живот појединима, његове одношаје спрам друштва, фамилије и државе, као што је то Ислам. Кур'ан задирући врло дубоко у казнено, насљедно, брачно, грађанско и - државно право, оставља законодавцима каснијих стољећа врло мало слободна простора за прилагођавање хисторијским нуждама тих касњих стољећа" (Sulejmanpašić 1918: 10).

${ }^{14}$ Радови Крајевске о остеомалацији били су први у области гинекологије и акушерства у Босни и Херцеговини (Alispahić 2016: 13).

15 „Највећу ипак пажњу посветила сам остеомалацији трудних жена. Не само што сам бележила презимена оболелих, него сам и детаљно истраживала анатомске промене које су постепено настајале у костима трупа. Ту ретку болест сам констатовала искључиво код муслиманских жена“ (Krajewska 1989: 100); „Пре мог доласка, остеомалација у Босни није била позната, што се лако тумачи изоловањем муслиманских жена од вањског света и недопуштањем мушком лекару да лечи муслиманке“ (Krajewska 1989: 102).

16 „Настајала је дезасимилација костију карлице, а постепено и кичме и ребара, у којима су, под дејством притиска, тегљења и подизања, настајале морфолошке промјене које су се погоршавале са сваком сљедећом трудноћом. Жене су трпеле болове у предјелу ребара, усљед њиховог размекшавања, а код сваке сљедеће трудноће болови су се ширили на карлицу и ребра, па је обољела жена била све више савијена према напријед. Да би се могла кретати, морала се ослањати на штапове, што је узроковало да већи дио дана проводи сједећи и тешко се помјерајући с мјеста на мјесто“" (Alispahić 2016: 12).

17 „Неплодна жена се сматрала као жена ниске вредности. Недостатак деце је темељни разлог за мужевљево тражење развода.“ У случају неплодности мужа „дешавало се да је такав бездетан 
мушкарац на дискретан начин тражио ‘помоћ’ од некога из породице или од најсрдачнијег пријатеља“" (Baranowski 1987: 52-53).

${ }^{18}$ Ова пракса повезана је с културом ислама јер се појављује на бројним местима, ипак „нема ништа заједничко са саветима Курана“ (Baranowski 1987: 53).

${ }^{19}$ Сулејманпашић доказује да је у Курану контекст покривања жена био потпуно другачији од контекста присутног у муслиманској средини у Босни (Sulejmanpašić 1918: 25-26).

20 „Та је забрана услиједила због тога, што њему научну, да се бос.-херц. муслимани икад просвијете и цивилизују јер је оружје било против освијештеног и национално пробуђеног српско-хрватског дијела нашег народа“" (Sulejmanpašić 1918: 3).

${ }^{21}$ У раду Zabilježene - Žene i javni život Bosne i Hercegovine u 20. vijeku аутори и ауторке указују на методу divide et impera, налазећи потврду у документима чиновника нове владе (Čaušević 2014: 17).

22 „Пошто испуни програм целог радног дана, без обзира на то где проводи слободно време, лекар може очекивати да буде позван да дође код оболеле особе јер је за сваки случај излазећи из куће јавио куда иде, ако би био потребан. За мене је тај непрекидан немир, то стално очекивање нечег незнаног, најнеугоднији фактор лекарске службе“ (Krajewska 1989: 91).

23 „Дете мушког пола родило се мртво, плацента је остала, конвулзије малтене без прекида, болесна жена без свести. Дакле, eclampsia puerperalis - Шта да радим? Никакве лекове не може да прими - рече др Дулер. - Одмах извући плаценту - одговарам. - Грлић материце је сужен. Ништа, прошириће се. - Да ли се прихватате операције? Пита ме др Дулер. - Jawohl, Herr Doktor - одговарам. Операција се завршила успехом. Конвулзије су се зауставиле одмах после операције [...] Други пут др Дулер ме је позвао такође због тешког порођаја. Положај детета је био попречан, при чему му је рука испадала. Окренула сам га ногама на доле и извукла дете. Доктору Дулеру се стално чинило да вучем преслабо. Одговарам му - само стрпљење, овде није потребна снага, рука ми и даље ради, не слаби. Овим путем успела сам спасити мајку. Дете је било мртво“ (Krajewska 1989: 90-91).

24 „Муслиманских пацијенткиња имала сам много. Имала сам велике тешкоће при посетама муслиманки из најсиромашније класе због планинског терена. Најсиромашнији део народа је живео међу стенама и у клисурама [...] Посебно је зими пењање по путевима исклесаним у стенама покривеним ледом или снегом било тежак задатак” (Krajewska 1989: 120).

25 „Негативна страна мог посла као државног лекара у тузланској општини била је недовољна плата [...] Трошкови су били велики: требало је да имам простран стан јер је у оквир мојих обавеза улазило одржавање бесплатне амбуланте за муслиманке [...] додуше, добивала сам од владе паушал за километре и тзв. 'дневнице' које ипак нису увек биле довољне да платим воз, хотел и живот у датом граду. Уредила сам такође захтев за повећање плате. Мало сам постигла jep су ми додали 200 гулдена годишње, као додатак за амбуланту, и то ad personam“ (Krajewska 1989: 104).

26 „Рађамо се женама или мушкарцима, али не мушким или женским. Женственост је нешто извештачено, неко достигнуће“" (Bartky 1990: 65). 


\section{Литература}

Alispahić, Nisveta. Dr. Teodora Krajewska. Prva liječnica-ginekolog u Tuzli i u Bosni i Hercegovini. Tuzla: Štamparija Off-set, 2016.

Assmann, Aleida. Między historia a pamięcia. Antologia. ur. Magdalena SaryuszWolska. Warszawa: Wydawnictwa Uniwersytetu Warszawskiego, 2013.

Baranowski, Władysław. Świat islamu. Łódź: TKKŚ, 1987.

Beauvoir, Simone de. Druga płeć. prev. Gabriela Mycielska, Maria Leśniewska, Warszawa: Czarna Owca, 2017.

Czajecka, Bogusława. „Uvod“. U: Pamiętnik, Teodora Krajewska, 5-22. Kraków: Krajowa Agencja Wydawnicza, 1989.

Čaušević, Jasmina, prir. Zabilježene - Žene i javni život Bosne i Hercegovine u 20. vijeku, Sarajevo: SOC, Fondacija CURE, 2014.

Duda, Maciej. Kobieta lekarz. XIX- i XX-wieczni publicyści oraz naukowcy o edukacyjnych i zawodowych możliwościach kobiety. U Kobieta, literatura, medycyna, ur. Arleta Galant, Agata Zawiszewska, 27-40. Szczecin: Wydawnictwo Naukowe Uniwersytetu Szczecińskiego, 2016.

Górska, Urszula. Drogi wolności: ruch emancypacyjny kobiet w monarchii habsburskiej na podstawie publicystyki i twórczości literackiej w latach 1867-1918. Warszawa: Instytut Badań Literackich PAN, 2016.

Hulewicz, Jan. „Wstęp“. U Pachucka, Romana, Pamiętniki z lat 1886-1914,. Wrocław: Zakład Narodowy im. Ossolińskich, 1958.

Hyży, Ewa. Kobieta. Ciało. Tożsamość. Teorie podmiotu w filozofii feministycznej końca XX wieku. Kraków: UNIVERSITAS, 2012. 
Kołodziejczyk, Beata. „Poród”. U Encyklopedia gender: płeć w kulturze. ur. RudaśGrodzka Monika, 401. Warszawa: Czarna Owca, 2014.

Krajewska, Teodora. Pamiętnik. ur. Bogusława Czajecka. Kraków: Krajowa Agencja Wydawnicza, 1989.

Sulejmanpašić, Dževad. Muslimansko žensko pitanje, jedan prilog njegovu riješenju. Sarajevo: Štamparija Daniel \& A. Kajan, 1918.

Solarska, Maria. „Płeć”. U Modi Memorandi: leksykon kultury pamięci, ur. Magdalena Saryusz-Wolska, Robert Traba, 367, Warszawa: Wydawnictwo Naukowe Scholar, 2014.

Zembrzuska, Agnieszka. „Problem ślepoty rodzajowej u Michela Foucault““. U Gender. Wizerunki kobiet $i$ mężczyzn w kulturze. ur. Durys Elżbieta, Ostrowska Elżbieta. Kraków: Rabid, 2005, (preuzeto: http://www.studiagender.umk.pl/pliki/teksty_zembrzuska_slepota_rodzajowa_foucaulta.doc $\underline{x})$.

\section{Интернет извори:}

http://www.czytelniamedyczna.pl/1551,osteomalacja.html (преузето 15. 7. 2021).

https://www.kcus.ba/historija_kcus.html (преузето 15. 7. 2021). 
Natalija Panas

natalia.panas@amu.edu.pl

Adam Mickiewicz University, Poznań

Institute of Slavic Philology https://doi.org/10.18485/knjiz.2021.11.11.8

UDC: 821.162.1.09-94 Крајевска T.

Original scientific article

\section{Teodora Kosmowska Krajewska's Memoirs: Emancipatory Discourse on the Position of Women in Bosnia and Herzegovina}

In this paper I analyse Memoirs, written by a Polish woman, Teodora (née Kosmowska) Krajewska (1854-1935), in the context of emancipatory discourse. The aim is to point out the strategies of Krajewska's actions towards the cultural and physical emancipation of Bosnian women in the aforementioned context, what obstacles she had to overcome in this process and why her Memoirs are important in the cultural memory of women's history. Krajewska worked as a doctor and teacher in Bosnia and Herzegovina for 34 years and made a strong impression there. Memoirs, as a bearer of memory, are important from the perspective of the history of women, herstory, especially the history of $\mathrm{BiH}$ Muslim women, who had no voice until then. They are also important as an exceptional element in the creation of a transnational network of female authorship narratives in general. One of the research perspectives in the context of winning a place for herstory in cultural memory is the experience of the female body. In this context, I give consideration to how understanding femininity through the prism of the body and its biological nature influences the process of forgetting/remembering and thus the absence/presence of narratives by women and about women in cultural memory. I refer, therefore, to the notion of gender in Maria Solarska's interpretation in Encyclopedia gender: pteć w kulturze (Encyclopaedia of Gender: Sex in Culture) and the description of the relationship between femininity and power by Agnieszka Zembrzuska in Problem ślepoty rodzajowej u Michela Foucault (The Problem of Gender Blindness in Michel Foucault). I place the category of Alaida Assmann's cultural memory, which she explains in the anthology Między historia a pamięcia (Between History and Memory), within this theoretical and methodological framework and I use it in correlation with the notion of corporeality as defined by Ewa Hyży in Kobieta. Ciało. Tożsamość. Teorie podmiotu w filozofii feministycznej końca $X X$ wieku (Woman. Body. Identity. Theories of the Subject in Feminist Philosophy at the End of the $20^{\text {th }}$ Century). In the paper, I follow the emancipatory steps of Krajewska, who educated and treated Bosnian women, sharply criticising them, but also offering her full understanding, empathy and affection. In a detailed and quite special way, Krajewska's autobiographical records show how a Polish physician influenced the process of the emancipation of Bosnian women.

Keywords: memoirs, herstory, emancipatory discourse, cultural memory, Teodora Krajewska 